\title{
HUMAN DEVELOPMENT INDEX IMPACT ON ECONOMIC GROWTH
}

\author{
Pham Tan Hoa ${ }^{1}$, Le Thanh Liem ${ }^{2, *}$, Nguyen Kim Phuoc ${ }^{3}$ \\ ${ }^{1}$ Kien Tuong Town, Long An Province, Vietnam. \\ ${ }^{2}$ People's Committees in Ho Chi Minh City, Vietnam. \\ ${ }^{3}$ Ho Chi Minh City Open University, Vietnam. \\ *Email: pthoavhung@yahoo.com.vn
}

(Received: March 30, 2016; Revised: May 07, 2016; Accepted: May 17, 2016)

\begin{abstract}
Several studies have explored the determinants of economic growth among countries. The research generally refers to factors such as physical capital/capital, labor, technology, infrastructure, policy institutions, the openness of the economy... However, previous studies rarely mention the human development index (HDI). This study reviewed the human development index (HDI) and other factors affecting the economic growth of nations. The research based on the theory of Solow (1956), Chiu, Hsu, \& Wang (2006) and Ferreira-Lopes Sequeira (2011). Reseach data from the data collected by the World Bank to analyze samples in 30 countries during the period (1999-2014). Table of data regression results table (Pooled, FEM and REM) show that HDI has a positive impact on economic growth of countries. Based on the study results, the recommendations are proposed in order to promote stability growth in countries and to ensure the harmony economic growth between and the goals of social development.
\end{abstract}

Keywords: GDP; HDI; Economic Growth.

\section{Introduction}

Some developed and developing countries have not only many development opportunities but also challenge to be addressed. Besides challenges such as underdeveloped infrastructure poor specialization and weak competitiveness, scientific qualification and technology as well as labor force skills shortage and income top also are major challenges. These challenges affect the stability development of nations. In the current period, a number of countries (including developed and developing countries) are losing the outside advantages, therefore, to ensure the quality of increase economy growth, sustainable growth, the country not only focuses on income increase but also notes in human development indicators. The success of a country cannot be measured by gross national income simply. Instead, people are the asset of the country and investment in human development is the best way to achieve growth and sustainable development.

HDI (1996), Human Development Index HDI is one of the socio-economic indicators of synthesis, measure of average achievements of a country, to be used as a basis for evaluating, comparing the levels of development of countries. Research "Human Development Index affecting economic growth" in countries targeted the relationship of indicates the human development index and economic growth of countries besides the common factors, such as physical capital, 
labor....From the research findings, recommendations are proposed to ensure the sustainable growth of the country, especially the developed and developing countries. Research content has 6 sections as follows: part 1: Foundationspart, part 2: Theoretical, part 3: Models and research data, part 4: Data analysis method, Part 5: Reseach results and part 6: conclusions and recommendations.

\section{Theoretical Foundations}

HDI (1996), Human development index HDI is a summary measure of human development in three basic dimensions: Income, as measured by GDP per capita (PPP USD), Knowledge, as measured by the literacy rate, Health, as measured by life expectancy at birth. To calculate the HDI, the following formula is used:

$$
\mathrm{HDI}=\frac{1}{3}\left(H D I_{1}+H D I_{2}+H D I_{3}\right)
$$

Where:

$\mathrm{HDI}_{1}$ : Index of GDP per capita (PPPUSD)

$\mathrm{HDI}_{2}$ : Knowledge index measured as the average of adult literacy rate (Population of age 15 and over who are able to read and write) with two-third weight and combined gross enrolment ratio for primary, secondary and tertiary education with one-third weight.

$\mathrm{HDI}_{3}$ : Index of average life expectancy at birth

HDI's value ranges from 0 to 1 . The nearer the HDI reach to 1 , the higher human development is, and vice versa.

$\mathrm{HDI}_{1}, \mathrm{HDI}_{2}$, and $\mathrm{HDI}_{3}$ are calculated as followed:

$$
H D I_{1}=\frac{\log \left(G D P_{\text {real }}\right)-\log \left(G D P_{\min }\right)}{\log \left(G D P_{\text {max }}\right)-\log \left(G D P_{\min }\right)}
$$

Neoclassical theory or endogenous growth model was initial developed by Solow (1956). This theory suggests that the source of the growth was derived from endogenous factors such as capital accumulation $(\mathrm{K})$ and labor $(\mathrm{L})$ and $\mathrm{Y}=\mathrm{f}(\mathrm{K}, \mathrm{L})$. Ferreira-Lopes \& Sequeira (2011) and Chiu et al. (2006) developed the endogenous growth model by adding the elements of human capital.

According to Sequeira \& Ferreira-Lopes (2011), human capital has the form: $\mathrm{H}=\mathrm{H}_{\mathrm{y}}+$ $\mathrm{H}_{\mathrm{h}}+\mathrm{H}_{\mathrm{s}}$ in which $\mathrm{H}_{\mathrm{y}}$ is the number of hours worked to create goods, $\mathrm{H}_{\mathrm{h}}$ is study hours and $\mathrm{H}_{\mathrm{s}}$ is hours learning participation activities which create social capital. According to Meier \& Stiglitz (2001), the level of economic growth is evaluated by indicators such as GDP/person, Human Development Index (HDI), the index of the degree of freedom (political freedom and freedom of production and business), only the value of the entertainment (cultural, ethical, ...).

Keynes (1936) says that the growth and development of the economy of a country depend mainly on government intervention through fiscal policy, monetary policy, public expenditure policy, public investment, ... Aggregate demand (AD) of the economy is formed as followed:

$$
\mathrm{AD}=\mathrm{C}+\mathrm{I}+\mathrm{G}+\mathrm{N}-\mathrm{X}
$$

In Which: $\mathrm{AD}$ is the aggregate demand of the economy, $\mathrm{C}$ is spending, $\mathrm{I}$ is investment, $\mathrm{G}$ is government spending, $\mathrm{N}$ is the total value of imports and $\mathrm{X}$ is the total value of exports.

According to Hughes (2012), government stimulates the demand in many ways including the method of stimulating consumption and production through increasing public spending to increase aggregate demand from the private sector (domestic and foreign). Aschauer (2000), Milbourne, Otto, \& Voss (2003) ... had shown that these is the relationship between economic growth and public investments. Sharma \& Panagiotidis (2005) say that the economies of the countries grow rapidly and stably based on import and export. Findings of Olugbenga \& Owoye (2007) show that, consumer price index (the index used as a measure of inflation) has a negative impact on economic growth of Negeria.

According to Putnam (1995), social 
capital consists of three main components: The moral norms, social values and civil society (participation in voluntary associations). Important components of social capital is social trust (Fukuyama, 1995). Putnam (1995) says that social beliefs, including belief in the institutional and legal system. Fukuyama (1995) says that social capital increases human capital, these two factors affect each other, trust each other to help people enjoy more success in the economic and social activities. Coleman (1988) identifies responsibilities, the expectations and beliefs of expression of social capital. According to Fukuyama (2001), social capital indicates confidence. The exchange and trust are the source of social capital (Thanh, 2016). Social trust has a close relationship with economic growth in recent decades. The countries with high social trust generally grow faster than other countries (Anh, 2011; Fukuyama, 1995).

Investments in health and education have been emphasized in the growth literature for their positive contributions. A series of papers by Boozer et al (2003), Ranis (2004), Ranis and Stewart (2004), Ranis and Stewart (2006) explore the two-way relationships between economic growth and human development, and argue that human development is not only a final product of the development process but also the means to generating future economic growth. It is argued that the strong economic growth advances human development through the increased household consumption expenditure as well as public expenditures, which directly give the benefit to the poor (Deb, 2015).

Permani (2008) used data in period from 1965 to 2000 and extended Solow's model for East Asia countries and had shown the human capital (measured by the number of years of study) has an impact on economic growth, apart from the contribution of the investment rate and population growth. According to Đat (2013), human capital has an impact on economic growth (GDP). Human capital can use many different metrics such as the percentage of workers to read and write; Graduation rate of labor at all levels (primary, lower secondary, ...); Years of schooling; ... The results of Đat (2013) showed that the average years of schooling of the workforce has an impact on economic growth (GDP).

Islam (1995) using panel data regression analysis to examine the relationship between real GDP and human development indicators in the developed countries. Human Development Index by 3 levels: high, medium and low. Human Development Index has the strongest impact on the changes in GDP/person in countries with lower Human Development Index. A relationship type ' $U$ ' between GDP/person and Human Development Index is for developing countries.

Khodabakhshi (2011), Importance of HDI led to review Indian economy. Trend changes every three human resource development index during the 30 - years period from 1980 to 2010 of the goals of this research. In this article, Khodabakhshi (2011) considers relationship between GDP and three indicators of human resources in India. This paper evaluates relationship and mutual effects the three indicators of human resource development in the Indian economy using the latest (2010) formula which provided by the United Nations. GDP or income as the dependent variable and three indicators long life, health and education as independent variables in the research model have been told. Founding in this article shows that GDP/capital index in the Indian economy has had good growth but the impact on other indicators of HDI is very low even on some indicators such as life expectancy has been ineffective. The results show that the HDI India is growing along with the downside. Growth index had a decreasing trend from the beginning period of 2009 and in its least 0.012 , but reached the year 2010 growth index 
has found the situation upside 0.014 is reached. India obtained 119 in world ranking HDI.

According to Deb (2015), the previous research (UNDP 1990 Stiglitz et al 2008, European Commission 2009, Costanza, et al 2009, Coyle 2014, Karabell 2014) has also indicated that a scatter plot of the HDI and GDP/preson or the correlation between the two reveals that the latter can statistically be as good as an indicator of progress as the latter. According to Deb (2015), this paper examines the rank differences between the two in a 140 country sample during four points of time (1990, 2000, 2010 and 2013) and also focuses on the sub-sample of countries with different income groups. The scatter plot, pearman's rank correlation and rank ordered logit and probit regression reveal that the two measures relate positively very strongly in the overall sample of all countries. But, the analysis for different income group of countries suggests that the positive relationship is more prominent for the low income countries and weakens for the middle and high income countries in all the years.

\section{Model và research data}

\subsection{Research model}

Based on the theory of Solow (1956), Keynes (1936), Hughes (2012), Sequeira \& Ferreira-Lopes (2011), and previous studies have related: Islam (1995), Meier \& Stiglitz (2001), Permani (2008), Đạt (2013),... Research model as follows:

Ln_ GDPper ${ }_{i t}=\beta_{0}+\beta_{1} *$ Ln $_{-}$CAPP $_{i t}+$ $\beta_{2} * \mathrm{RLABOR}_{\mathrm{it}}+\beta_{3} * \mathrm{SGOV}_{\mathrm{it}}+\beta_{4} * \mathrm{OPEN}_{\mathrm{it}}+$ $\beta_{5} * \mathrm{INF}_{\mathrm{it}}+\beta_{6} * \mathrm{HDI}_{\mathrm{it}}+\beta_{7} * \mathrm{TRUST}_{\mathrm{it}}+$ $\beta_{8} *$ DEVELOPED $+\mathrm{u}$

With i: Representing national

$\mathrm{i} ; \mathrm{i}=1 ; 2 ; 3 ; 4 ; \ldots . . ; 30$

$\mathrm{t}$ : Representing year $\mathrm{t}$;

$\mathrm{t}=1999,2009$ and 2014

$\mathrm{u}$ : Error

$\beta_{0}$ : Original Score

$\beta_{1} \ldots .8$ : The estimated coefficient of the independent variable.

Table 1. Description of the variables in the model study

\begin{tabular}{|c|c|c|c|c|}
\hline Variables & $\begin{array}{c}\text { Name (variable } \\
\text { of sign }\end{array}$ & Unit of measurement & $\begin{array}{l}\text { Previous research } \\
\text { related }\end{array}$ & $\begin{array}{l}\text { Expected } \\
\text { sign }\end{array}$ \\
\hline $\begin{array}{l}\text { GDP per } \\
\text { population }\end{array}$ & Ln_GDPper & $\begin{array}{l}\text { Is GDP at USD } 2011 \\
\text { is that power parity } \\
\text { adjustment purchase } \\
\text { (PPP) divided by the } \\
\text { total population } \\
\text { (logarit_GDPper) }\end{array}$ & \multicolumn{2}{|c|}{ Dependent variable } \\
\hline $\begin{array}{l}\text { Logarithm of } \\
\text { the value of the } \\
\text { country's } \\
\text { physical capital }\end{array}$ & Ln_CAPP & $\begin{array}{l}\text { Physical capital } \\
\text { (investment) includes } \\
\text { expenditures for } \\
\text { additions to fixed assets } \\
\text { of the economy plus the } \\
\text { change in inventories, } \\
\text { which are calculated } \\
\text { according to a fixed } \\
\text { price of USD 2005. }\end{array}$ & $\begin{array}{l}\text { Aschauer (2000), } \\
\text { Milbourne, Otto, \& } \\
\text { Voss (2003), Afonso, } \\
\text { Schuknecht, \& Tanzi } \\
(2010), \\
\text { Hughes (2012) }\end{array}$ & + \\
\hline Social capital & TRUST & $\begin{array}{l}\text { The percentage of } \\
\text { those surveyed } \\
\text { responded that they } \\
\text { trust others }(\%)\end{array}$ & $\begin{array}{l}\text { Coleman (1988), } \\
\text { Fukuyama (2001), Chiu, } \\
\text { Hsu, \& Wang (2006) }\end{array}$ & + \\
\hline
\end{tabular}




\begin{tabular}{|c|c|c|c|c|}
\hline Variables & $\begin{array}{l}\text { Name (variable } \\
\text { of sign }\end{array}$ & Unit of measurement & $\begin{array}{c}\text { Previous research } \\
\text { related }\end{array}$ & $\begin{array}{l}\text { Expected } \\
\text { sign }\end{array}$ \\
\hline $\begin{array}{l}\text { Human } \\
\text { development } \\
\text { index - HDI }\end{array}$ & HDI & $\begin{array}{l}\text { Summary measure of } \\
\text { human development in } \\
\text { three basic } \\
\text { dimensions: Income, } \\
\text { Knowledge and Health } \\
(\%)\end{array}$ & $\begin{array}{l}\text { Islam (1995), Meier \& } \\
\text { Stiglitz (2001), Permani } \\
\text { (2008), Đạt (2013), } \\
\text { Sequeira \& Ferreira- } \\
\text { Lopes (2011) }\end{array}$ & + \\
\hline $\begin{array}{l}\text { Percentage of } \\
\text { workers/ } \\
\text { population }\end{array}$ & RLABOR & $\begin{array}{l}\text { is calculated by the } \\
\text { percentage of the } \\
\text { number of workers in } \\
\text { the age of } 15 \text { and older } \\
\text { participated in work } \\
\text { on total population } \\
(\%)\end{array}$ & $\begin{array}{l}\text { Chiu et al. (2006) } \\
\text { Permani (2008), } \\
\text { Sequeira \& Ferreira- } \\
\text { Lopes (2011) }\end{array}$ & + \\
\hline $\begin{array}{l}\text { Openness of the } \\
\text { national } \\
\text { economy }\end{array}$ & OPEN & $\begin{array}{l}\text { Openness of the } \\
\text { national economy as } \\
\text { measured by the total } \\
\text { value of import and } \\
\text { export and is } \\
\text { calculated as a } \\
\text { percentage of GDP } \\
(\% / G D P)\end{array}$ & $\begin{array}{l}\text { Keynes (1936), Sharma } \\
\text { \& Panagiotidis (2005) }\end{array}$ & + \\
\hline Inflation & INF & Inflation rate $(\%)$ & $\begin{array}{l}\text { Keynes (1936), } \\
\text { Olugbenga \& Owoye } \\
(2007)\end{array}$ & - \\
\hline $\begin{array}{l}\text { Government } \\
\text { Spending }\end{array}$ & SGOV & $\begin{array}{l}\text { Government spending } \\
\text { on goods and services } \\
\text { is calculated as a } \\
\text { percentage of GDP } \\
(\% / G D P)\end{array}$ & $\begin{array}{l}\text { Aschauer (2000), } \\
\text { Milbourne et al. (2003), } \\
\text { Hughes (2012) }\end{array}$ & + \\
\hline $\begin{array}{l}\text { Developed } \\
\text { nation } \\
\text { (Dunning } \\
\text { variable) }\end{array}$ & DEVELOPED & $\begin{array}{l}\text { This variable }=1 \text { if the } \\
\text { value is the developed } \\
\text { and developing } \\
\text { country, getting value } \\
=0 \text { if the country is } \\
\text { underdeveloped (as } \\
\text { ranked by the World } \\
\text { Bank) }\end{array}$ & $\begin{array}{l}\text { Keynes (1936), Islam } \\
(1995)\end{array}$ & + \\
\hline
\end{tabular}

\subsection{Research data}

The index of GDP/per, CAPI, HDI, RLABOR, TRUST, INF, OPEN, SGOV and DEVELOPED collected from statistics data of the World Bank (WB) in the surveying period social confidence index (per period).
Indicators of social trust were collected from the survey results of the World Bank (WB) for the period (1999 - 2014). On average, each stage included more than 50 countries with more than 70,000 participants per survey, namely: Phase (1995 - 1998) 
surveyed in 52 countries, with 74548 people interviewed (published in 1999); Phase (2005 2009) surveyed in 57 countries, with 80987 people interviewed (published in 2009); Phase (2010 - 2014) surveyed in 55 countries, with 79,805 people interviewed (published in 2014).

However, 30 countries that had participated fully in the period (1999 - 2014) should be selected for analysis to ensure the balance of the panel data, while 13 countries had been developed and 17 underdeveloped countries. Thus, the number of used observations are 90 observations (30 countries in 3 stages), with the number of 235,340 people were interviewed about social confidence index.

\section{The method of data analysis}

The regression model respectively implemented as: Model Pooled (pooled regression model - Pooled), regression model fixed effects (FEM) and regression models with random effects (REM) of the cross units, from the analysis picked out a suitable model.

According Maddala (1987), the Wald test for the purpose of determination of the original launch of the crossover unit (30 countries) is equal or not, if that is agreed by each case coefficients and coefficients vertical axis unchanged slope, or Pooled model is suitable and vice versa, as appropriate FEM models.

According Baltagi (2008), Hausman test is done to choose between FEM and REM model $\mathrm{H}_{0}$ hypothesis that there is no difference between FEM and REM method, if the value of accreditation Hausman Prob $\leq \alpha$ $=5 \%$ then reject the hypothesis $\mathrm{H}_{0}$ suitable FEM models ie, opposite the REM model will be selected.

According Baltagi (2008), testing the error variance changes is made according to the method of Breusch \& Pagan (1979), based on the value of the index Prob Chi-square test to decide whether to accept or reject the null hypothesis $\mathrm{H}_{0}$, if Prob $\leq \alpha=5 \%$, not reject $\mathrm{H}_{0}$ hypothesis, ie the model does not occur error variance change, and vice versa, if the model is violated error variance changes, it will proceed Robust overcome by the tool (Gujarati, 2009).

\section{Research results}

\subsection{Descriptive statistical analysis}

Table 2. Statistics describing the variables in the model

\begin{tabular}{|l|r|r|r|r|}
\hline \multicolumn{1}{|c|}{ Variable } & \multicolumn{1}{c|}{ Mean } & \multicolumn{1}{c|}{ Std. Dev. } & \multicolumn{1}{c|}{ Min } & \multicolumn{1}{c|}{ Max } \\
\hline GDPper & 17230.5 & 12769.06 & 620.54 & 22633.85 \\
\hline CAPP & $2.47 \mathrm{e}+11$ & $5.43 \mathrm{e}+11$ & $6.44 \mathrm{e}+08$ & $2.88 \mathrm{e}+12$ \\
\hline RLABOR & 53.74 & 8.454275 & 31.86 & 74.5 \\
\hline SGOV & 15.6697 & 4.217827 & 7.029498 & 25.74925 \\
\hline OPEN & 63.4013 & 27.46236 & 18.9044 & 139.3756 \\
\hline INF & 10.911 & 17.44757 & -1.013762 & 107.8883 \\
\hline HDI & 0.729 & 0.1241308 & 0.4384 & 0.9306 \\
\hline TRUST & 25.3319 & 14.41325 & 3.2 & 65.2 \\
\hline DEVELOPED & 0.42857 & 0.4976134 & 0 & 1 \\
\hline \multicolumn{2}{|r|}{ Number of obs $=30$, include 13 countries have been developed, 17 countries } \\
\multicolumn{7}{|r|}{ have not developed } \\
\hline
\end{tabular}


Researchers analyzed data from 30 countries (include Developed Countries 13, 17 underdevelop Countries) therefore, GDP/person in population (GDPper), physical capital (CAPP), government spending (SGOV), the openness economy (OPEN) and the percentage of workers (RLABOR) significant differences exist among countries. GDPper on average in countries around 17230.5 USD, the lowest only 620.54 USD - this is not a developing country. The developed countries, up to 22633.85 USD GDPper - this income is relatively high. Physical capital (investment) is in countries with significant differences, with countries investment up to $2.88 \mathrm{e}^{+12}$ USD but also national level only $6.44 \mathrm{e}^{+08}$ USD. This may be the national budget, the situation of economic development, investment environment,... in the different countries. By the government's spending in these countries there is a huge difference, some countries spend up to $25.74925 \%$ government/GDP, there are countries this figure is only $7.029498 \% / G D P$. The percentage of national workers as well, quite separate, with only $31.86 \%$ country's population of working age in the labor force participation, with the national rate of $74.5 \%$ is up to. Economic growth in the countries is not even due to the large gap in the above-mentioned factors.
Inflation indicators in the national average of about $10 \%$, but there are high inflation countries (Table 3) and deflation countries. This led to the macroeconomic policies of various countries and hence the impact of the national GDP, as usual, to control inflation, countries usually sacrifice economic growth (accepted economic growth is lower).

The highest HDI of the countries in the study sample is 0.93 . This index has a large gap between countries and nation evidence, this indicator is only at 0.4384 . The average of the samples is reaching 0.729 HDI. There are countries with a high HDI (close to 1) and the country below the average HDI $(\leq 0.5)$, so, human development in countries with large differences, living standards and living conditions of the people people in these countries does not have equal.

According to the World Bank's survey results, the index of the average social trust at $25 \%$ means that only amounts to $25 \%$ of respondents claim to have faith in others. The index is quite small. This reflects the current status quo society, trust in others very little, because the elements of ethics, personality, ... has not been much attention, passive attitude to the indifference to the moral values, the complexity of society, ... this can affect the social, human life and national development.

\subsection{Test correlation matrix and multicollinearity}

Table 3. Test correlation matrix and multicollinearity

\begin{tabular}{|l|r|r|r|r|r|r|r|c|}
\hline & Ln_CAPP & RLABOR & SGOV & OPEN & INF & HDI & TRUST & DEVELOPED \\
\hline Ln_CAPP & 1.00 & & & & & & & \\
\hline RLABOR & 0.364 & 1.00 & & & & & & \\
\hline SGOV & 0.017 & -0.185 & 1.00 & & & & & \\
\hline OPEN & -0.501 & -0.263 & 0.306 & 1.00 & & & & \\
\hline INF & -0.295 & -0.110 & -0.018 & 0.034 & 1.00 & & & \\
\hline HDI & 0.434 & 0.306 & 0.433 & 0.052 & -0.278 & 1.00 & & \\
\hline TRUST & 0.395 & 0.242 & 0.384 & -0.109 & -0.176 & 0.375 & 1.00 & \\
\hline DEVELOPED & 0.367 & 0.181 & 0.254 & -0.065 & -0.255 & 0.772 & 0.317 & 1.00 \\
\hline VIF & $\mathbf{2 . 1 1}$ & $\mathbf{1 . 4 8}$ & $\mathbf{1 . 8 7}$ & $\mathbf{1 . 6 9}$ & $\mathbf{1 . 1 6}$ & $\mathbf{3 . 9 7}$ & $\mathbf{1 . 5 3}$ & $\mathbf{2 . 7 0}$ \\
\hline
\end{tabular}


Gujarati (2009) say that, there are two commonly used signs to identify signs of multicollinearity between the variables in the model is to use the correlation coefficient pair and VIF. The correlation coefficient pair (pairwise correlation) among the independent variables is greater than 0.85 multicollinearity occurs between variables. The correlation coefficient between pairs highly makes VIF coefficients greater than 10, the pair of variables can occur multicollinearity. To ensure there are no multicollinearity cases occur in the model, the research is completed with the analysis step correlation coefficient matrix and multi-line community to ensure greater reliability, and more precise estimated.

According to the results of correlation analysis (Table 3) we see, all the variables are highly correlated factor $\leq 0.5$, simultaneously, the ratio is less than 10 VIF, VIF biggest variable is 3.97 (HDI variables). Thus, the variables in the model have no multicollinearity phenomenon occurs. This makes the subsequent regression estimates to ensure highly accuracy.

\subsection{Regression analysis results}

Wald test result, Prob $=0.0000$ value $<\alpha$ $=0.05$ level should reject $\mathrm{H}_{0}$ hypothesis, as such, there is a difference between the y-axis coefficient between independent variables, therefore, more suitable model FEM model Pooled picture. Hausman test results for Prob $=0.0000<\alpha=0.05$ level should reject $\mathrm{H} 0$ hypothesis, ie, more suitable model FEM model REM.

However, testing the error variance changes in model FEM (xttest3) shows, Prob> chi $2=0.0000$, meaning that they are infringed model error variance change. Scrabble effect using regression Robust tools to control the phenomenon of error variance change. Robust regression results are as follows:

Table 4. Regression results (Robust)

\begin{tabular}{|c|c|c|c|}
\hline Variable & Coef. & Robust Std. Err. & $\mathrm{P}>\mathrm{Z}$ \\
\hline Ln_CAPP & $0.1094413 * * *$ & 0.0301 & 0.000 \\
\hline RLABOR & $0.0138546 * * *$ & 0.0053 & 0.008 \\
\hline SGOV & -0.0100 & 0.0098 & 0.308 \\
\hline OPEN & -0.0009 & 0.0015 & 0.546 \\
\hline INF & -0.0005 & 0.0020 & 0.806 \\
\hline HDI & $5.271335 * * *$ & 0.6788 & 0.000 \\
\hline TRUST & 0.0010 & 0.0965 & 0.649 \\
\hline DEVELOPED & 0.1532 & 0.0965 & 0.112 \\
\hline \multicolumn{4}{|c|}{ sigma_u $=0.1992236$} \\
\hline \multicolumn{4}{|c|}{ sigma_e = 0.093806} \\
\hline \multicolumn{4}{|c|}{ rho $=0.80767754$} \\
\hline \multicolumn{4}{|c|}{ R-sq (within) $=0.8346$} \\
\hline \multicolumn{4}{|c|}{ Wald chi2 $(8)=681.86$} \\
\hline \multicolumn{4}{|c|}{ Prob $>\operatorname{chi} 2=0.0000$} \\
\hline$* * *:$ Statistical & ance level $1 \%$ & & \\
\hline
\end{tabular}


According to the regression results (already controlling error variance phenomenon changes) show (Table 4): physical capital (CAPP), the percentage of workers (RLABOR) and the Human Development Index (HDI) has positive impact on economic growth (GDP/person) of countries with statistical significance level of $1 \%$. Factors such as: SGOV, OPEN, INF, TRUST and found no signs Developed impact on economic growth (GDP/per) of these countries.

Physical capital/capital (CAPP) have an impact on GDP/per with a statistical significance of $1 \%$ and coef. $=0.1094413$, meaning that if the other factors are constant, physical capital (CAPP) increased 1 USD is GDPper $0.1094413 \%$ increase. Findings correct initial expectations and consistent with previous studies of: Aschauer (2000), Milbourne et al. (2003), Afonso et al. (2010), Hughes (2012). Physical capital is always needed in the economic development of nations, whether developed countries or undeveloped. Increased investment to help the economy grow is a perfect fit.

Labor ratio (RLABOR) has an impact on GDP/per with a statistical significance of $1 \%$ and coef. $=0.0138546$ means if other factors remain unchanged, labor rate (RLABOR) increased 1\%, GDPpre $0.0138546 \%$ increase. Findings correct initial expectations, in line with the theory of Solow (1956) and consistent with previous studies of: Chiu et al. (2006), Permani (2008), \& Ferreira-Lopes Sequeira (2011). Thus, countries with labor ratio (RLABOR) rose $1 \%$, the growth of the national economy that is capable of $0.0138546 \%$ increase compared to other countries.

HDI has an impact on GDP per statistically significant at $1 \%$ and coef. = 5.271335, which means that if other factors are equal, countries with HDI increased by 1 unit, is higher economic growth in other countries $5.271335 \%$. This is the most powerful variable (for 3 variables have statistically significant) to GDPper. Findings correct initial expectations and consistent with previous studies of: Islam (1995), Meier \& Stiglitz (2001), Permani (2008), Đat (2013), $\&$ Ferreira-Lopes Sequeira (2011). Thus, the HDI has a strong impact on economic growth of the country, therefore, the countries which want rapid and sustainable development need to implement social policies and policies to support, promote human development.

Human Development Index (HDI) is a comparative index, quantified in terms of income, literacy, life expectancy and other factors some of the countries in the world. This is also a measure of the level of general well-being of people in daily life based on basic criteria such as income, knowledge, health, poverty, unemployment ... Therefore, this index is also called "happiness index". Considering the significance of the HDI, the level of happiness or the level of human development is not proportional to income, but it depends on the person using that income like.

\section{Conclusion and Recommendations}

\subsection{Conclusion}

This paper was based on data of the WB to review HDI impact on economic growth of the 30 countries stage (1990 - 2014). Results of regression analysis of the data in the table with $3 / 8$ independent variables affects the dependent variable. Three variables that have positive impacts on GDPper in nations are: HDI, CAPP and RLABOR, in which the most powerful HDI is largest regression coefficient. Thus, the HDI is an important factor affecting GDPper of countries besides the usual factors such as capital and labor.

\subsection{Recommendations}

To promote economic growth, countries must always increase physical capital investment and increase the workforce. However, the next two fixed elements of them, the country wants to ensure economic growth and sustainable quality, which must 
focus on the human element. High qualified human resources are seen as an invaluable asset of a nation, is mental strength and wisdom of nations. Investing in people is investing long-term development of the country. Human Development Index is one of the key indicators of the economic development of each country and is believed to be effective in the role of economic development. Human Development Index allows assess more accurately the achievements of the country. Human development is to ensure that people can live a long life healthies and more effective, and not merely the wealth of the economy of place people live. Governments need to define sustainable development goals which is to create conditions where people can live a long life, good health, good knowledge, high working efficiency bring long-term benefits for the country. Governments should review social policies and invest more for the cause of education, health, promotion of social welfare programs to help to increase the human lifespan, people live healthier, better living conditions, higher levels of education, ... so that nation can ensure sustainable and more qualified economic growth.

At the same time, households and people need to focus on spending on education, health, income distribution an effective way to make sure people have a long life, good health, good living, access to knowledge and wisdom, labor efficiency, contributing to bring truly sustainable wealth for each country.

\section{REFERENCES}

Afonso, A., Schuknecht, L., \& Tanzi, V. (2010). Public sector efficiency: evidence for new EU member states and emerging markets. Applied Economics, 42(17), 2147-2164.

Anh, N. T. (2011). Social capital and the need to study social capital in rural Vietnam today.

Aschauer, D. A. (2000). Do states optimize? Public capital and economic growth. The annals of regional science, 34(3), 343-363.

Boozer, M., Ranis, G., Stewart F. and Suri, T. (2003). Paths to Success: The Relationship between Human Development and Economic Growth, Discussion Paper No. 874, Economic Growth Center, Yale University: New Haven, Available in http://ssrn.com/abstract=487469.

Chiu, C.-M., Hsu, M.-H., \& Wang, E. T. (2006). Understanding knowledge sharing in virtual communities: An integration of social capital and social cognitive theories. Decision support systems, 42(3), 1872-1888.

Deb, S. (2015). Gap between GDP and HDI: Are the Rich Country Experiences Different from the Poor?, Paper Prepared for the IARIW - OECD Special Conference: "W(h)ither the SNA?", Paris, France, April 16-17, 2015.

Đạt, T. T. (2013). The role of human capital in growth models. Economic Studies, 393(2), 3-10.

Fukuyama, F. (1995). Trust: The social virtues and the creation of prosperity: JSTOR.

HDI, U. (1996). Human Development Index. United Nation Development Program-1996. 
Hughes, O. E. (2012). Public management and administration: Palgrave Macmillan.

Islam, S. (1995). The human development index and per capita GDP. Applied Economics Letters, 2(5), 166-167.

Khodabakhshi, A. (2011). Relationship between GDP and human development indices in India. In Society of Interdisciplinary Business Research (SIBR) 2011 Conference on Interdisciplinary Business Research.

Keynes, J. M. (1936). Allgemeine Theorie der Beschäftigung, des Zinses und des Geldes (Vol. 6): Berlin.

Meier, G. M., \& Stiglitz, J. E. (2001). Frontiers of development economics: The future in perspective: World Bank Publications.

Milbourne, R., Otto, G., \& Voss, G. (2003). Public investment and economic growth. Applied Economics, 35(5), 527-540.

Olugbenga, A., \& Owoye, O. (2007). Public expenditure and economic growth: New evidence from OECD countries. Business and Economic Journal, 4(17).

Permani, R. (2008). Education as a determinant of economic growth in East Asia: Historical trends and emphirical evidences (1965-2000). Paper presented at the Asia-Pacific Economic and Business History Conference (2008: Melbourne, Australia).

Ranis, G., (2004). Human Development and Economic Growth, Discussion Paper No. 887, Economic Growth Center, Yale University: New Haven, Available in: http://ssrn.com/abstract=551662

Ranis, G. and Stewart, F. (2004). Dynamic links between the Economy and Human Development, United Nations Department of Economic and Social Affairs (UN-DESA) Working Paper No. 8, UN: New York, Available in http://www.un.org/esa/desa/papers.

Ranis, G. and Stewart, F. (2006). Successful Transition towards a Virtuous Cycle of Human Development and Economic Growth: Country Studies, Discussion Paper No. 943, Economic Growth Center, Yale University: New Haven, Available in: http://ssrn.com/abstract=920603.

Sequeira, T. N., \& Ferreira-Lopes, A. (2011). An endogenous growth model with human and social capital interactions. Review of Social Economy, 69(4), 465-493.

Sharma, A., \& Panagiotidis, T. (2005). An analysis of exports and growth in India: cointegration and causality evidence (1971-2001). Review of Development Economics, 9(2), 232-248. 